\begin{tabular}{|l|l|l}
\hline Received: Maret 2019 & Accepted: April 2020 & Published: April 2020
\end{tabular}

\title{
Rancang Bangun Biometric Starting System Berbasis Microcontroller Atmega328p Untuk Operator Berat Dozer D3k Caterpillar
}

\author{
Abdul Halim ${ }^{*}$, Mangkona ${ }^{2}$, Rovi Zakiratul Zuhri ${ }^{3}$ \\ ${ }^{1,2,3}$ Politeknik Negeri Samarinda \\ *halim72@polnes.ac.id
}

\begin{abstract}
Heavy equipment industry is an employment sector with potentially high rate of accidents, which might occur due to the operator's own fault, where he or she does not have competence in operating such an equipment. This operator's fault accident ranks number two after that of the mechanic's accident rate, which is the focus of this research. In line with the latest digital electronic development, companies have been able to solve problems confronted with operators, one of which is through the application of biometric authorization device, which has been expected to be able to reduce the rate in the industrial accidents in heavy equipment rental. This device works by requiring authorization of the operator without inserting the manually inserted Ignition key to the machine, but the operator' fingerprint that has been authorized into the system to operate such a machine. This, in turn, Will be able to reduce risks of getting an accident among operators. Fingerprint has its function to recognize the operator's identity as well as password to the electronic Ignition key to the machine that not everybody can get access to operating the machine to start it up. Design of this electronically control device is to produce biometrically engine start-up replacing the currently recognize Ignition switch to crank and switch off the engine using microcontroller ATmega328P system. Results of the study gained from the tests based on the standard operating procedures show based on the standard Operating procedures show a $100 \%$ success without any obstacles
\end{abstract}

Keywords : biometric, starting system, mokrokontroller, fingerprint

\begin{abstract}
Abstrak
Industri alat berat merupakan lapangan pekerjaan yang dimana memiliki tingkat kecelakaan kerja yang tinggi, banyak kecelakaan kerja terjadi dikarenakan kesalahan operator alat berat itu sendiri, baik itu karena operator tersebut tidak memiliki kompetensi keahlian dalam mengoperasikan kendaraan alat berat tersebut, sehingga operator alat berat menjadi pekerjaan dengan tingkat kecelakaan tertinggi kedua setelah mekanik, itulah yg menjadi dasar penelitian ini dilakukan. Seiring dengan perkembangan teknologi elektronika digital dewasa ini, maka persoalan-persoalan yang dihadapi mampu untuk dipecahkan dan disolusikan yang dialami perusahaan terhadap para operator dilapangan, salah satunya adalah biometric authorization, yang diharapkan dapat mengurangi tingkat kecelakaan kerja didunia industri rental alat berat yang pekerjaannya memerlukan proses otorisasi para operatornya, dimana yang biasanya autorisasi tersebut biasanya menggunakan kunci kontak akan diganti dengan sidik jari (fingerprint). hanya operator yang telah terotorisasilah yang dapat masuk kedalam sistem tersebut untuk mengoperasikan unit. Sehingga diharapkan dapat meminimalisir kecelakaan kerja dikalangan operator. Fingerprint berfungsi sebagai identitas operator dan password sebagai kunci elektroniknya. Dengan menggunakan fingerprint seseorang tak akan mudah mengoperasikan unit dengan sembarangan karena hanya sang operator yang sudah terotorisasi yang bisa starting engine. Tujuan dari pembuatan alat ini adalah untuk merancang dan membuat biometric starting engine otomatis menggantikan fungsi key star switch yang selama ini digunakan untuk cranking engine dan turn off the engine dengan kendali akses menggunakan fingerprint dan password berbasis mikrokontroler ATmega328P. Hasil yang diperoleh dari pengujian berdasarkan SOP yang telah dibuat berhasil 100\% tanpa ada problem.
\end{abstract}

Kata kunci : biometric, starting system, microcontroller, fingerprint 


\section{Pendahuluan}

Perkembangan sains dan teknologi akan melahirkan berbagai solusi untuk memecahkan permasalahan manusia. Masalah yang timbul, akibat terbatasnya kemampuan manusia ataupun dari factor lain, kini sedikit demi sedikit dapat teratasi salah satu solusi yang dapat membantu permasalahan manusia yaitu dengan menggunakan system kendali berbasis komputer. Salah satunya adalaha starting system yang menggunakan otorisasi sidik jari.

Biometrika merupakan suatu metode pembuktian dan pengenalan otomatis identitas dari seseorang berdasarkan guratan-guratan jari. Biometrika sidik jari memiliki tingkat akurasi yang sangat tinggi, karena dinyatakan hampir semua individu tidak ada memiliki guratan sidik jari yang sama. Sistem pengamanan sidik jari sangat baik untuk di terapkan. Dengan adanya otorisasi sidik jari hanya orang yang memiliki otoritas saja yang dapat menyalakan atau mengoperasikan alat/kendaraan tersebut. Beberapa penelitian sebelumnya yang sudah dilakukan dengan membuat kunci pagar menggunakan Fingerprint Berbasis Mikrokontroler ATmega328P [1]. Begitu pula penelitian akses control pintu ruangan menggunakan sidik jari yang berbasis ATmega 328P [2] dan akses control pintu ruangan menggunakan sidik jari yang berbasis jari dikembangkan dengan smartphone android [3]. Dan bahkan keamanan pintu brankas menggunakan sensor sidik jari dan password digital dengan mikrokontroler ATmega 19 [4]

\section{Tinjauan Pustaka}

\section{Dasar Kelistrikan Alat Berat}

Pada unit alat berat rangkaian starting mempunyai perangkat pengontrol dan pelindung. Perangkat ini digunakan untuk mengoperasikan motor starter dan mencegah operasi pada saat mesin dalam keadaan mode operasi karena alasan safety. Motor Starter membutuhkan sumber tenaga untuk menggerakkanya.

Penulis mengacu pada schematic electric Dozer D3K Caterpilar yang diterbitkan oleh media number KENR5711-04, untuk mengetahui rangkaian kelistrikan pada unit tersebut, yang kemudian digunakan sebagai referensi mengetahui rangkaian kelistrikan pada unit tersebut agar nantinya unit tersebut dapat dikontrol dengan alat yang di buat. [5]

Komponen pada sistem kelistrikan tersebut pada gambar 1, antara lain baterai (1), disconnect switch (2), alternator breaker (3),

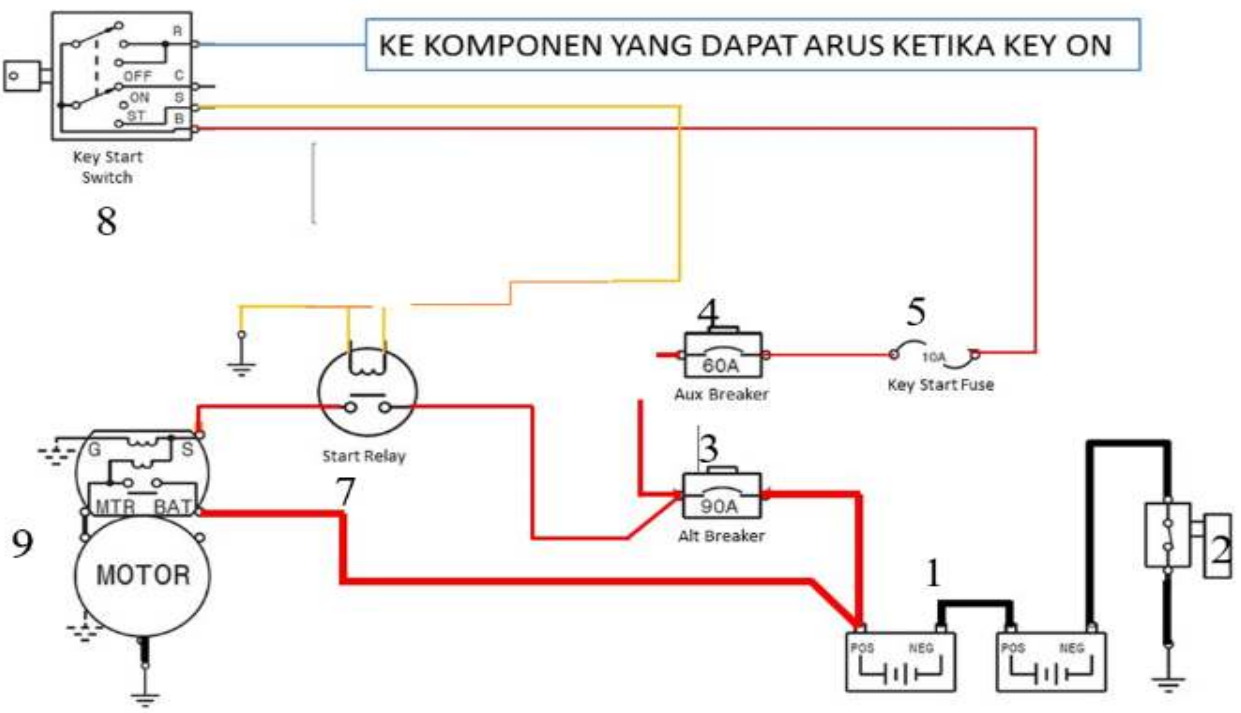

Gambar 1 Skematik sistem kelistrikan dasar starting system D3K 
aux breaker (4), key start fuse (5), start relay (6), key start switch (7) dan starter motor (8). Semua komponen tersebut berkerja bersama agar unit alat berat dapat menyala [6].

\section{Fingerprint}

Fingerprint adalah salah satu bentuk biometrik, sebuah ilmu yang menggunakan karakteristik fisik penduduk untuk mengidentifikasi. Sidik jari sangat ideal untuk tujuan ini karena mereka murah untuk mengumpulkan dan menganalisis dan mereka tidak pernah berubah, bahkan dengan umur orang.

Meskipun tangan dan kaki memiliki banyak daerah bergerigi yang dapat digunakan untuk identifikasi, sidik jari menjadi bentuk populer biometrik karena mereka mudah untuk mengklasifikasikan dan mengurutkan. Mereka juga dapat diakses.

Teknologi fingerprint merupakan salah satu cara yang paling aman karena fingerprint tidak bisa dimanipulasi data. Fingerprint telah terbukti cukup akurat, aman, mudah dan nyaman untuk dipakai sebagai identifikasi bila dibandingkan dengan system yang lainnya retina mata atau DNA. Hal ini dapat dilihat pada sifat yang dimiliki oleh sidik jari, antara lain [7] :

1. Perennial nature, yaitu guratan-guratan pada sidik jari yang melekat pada kulit manusia seumur hidup;

2. Immutability, yaitu sidik jari seseorang tidak pernah berubah, kecuali mendapatkan kecelakaan yang serius;

3. Individuality, pola sidik jari adalah unik dan berbeda untuk setiap orang.

Ketiga sifat ini, sidik jari dapat digunakan sebagai system identifikasi dalam aplikasi teknologi informasi seperti :

a. Access System Security, yaitu akses untuk masuk ke suatu area atau ruangan tertentu yang terbatas;

b. Authentification System, yaitu akses data yang sifatnya rahasia dan terbatas.

Secara sederhana fingerprint bekerja dengan "merekam" sidik jari seseorang, lalu menyimpan pola khasnya. Identifikasi dilakukan dengan mencocokkan data yang telah tersimpan tersebut. Jika dinyatakan sama, akses otomatis terbuka. Sidik jari terdiri dari banyak garis menonjol yang cenderung melingkarlingkar. Hal ini bisa terlihat jelas, salah satunya ketika kita membuat cap jari menggunakan tinta untuk surat-surat resmi. Dari situ bisa dilihat, satu sidik jari saja memiliki banyak pola rumit. Jika semua pola ini digunakan, proses identifikasi sidik jari akan memakan waktu terlalu lama. Sebaliknya, jika pola yang diambil terlalu sederhana, kemungkinan pemindaian kurang akurat. Sebagai solusi, mesin pemindai hanya menangkap dan menyimpan tiga jenis pola pada guratan sidik jari. Pola diambil dari bagian yang pada hasil cap jari tintanya terlihat lebih tebal. Pola itu di antaranya, ujung garis (ridge ending), garis bercabang (bifurcation), dan garis pendek menyerupai titik (short ridge). Tiga detail pada sidik jari ini tak pernah ditemui sama pada manusia:

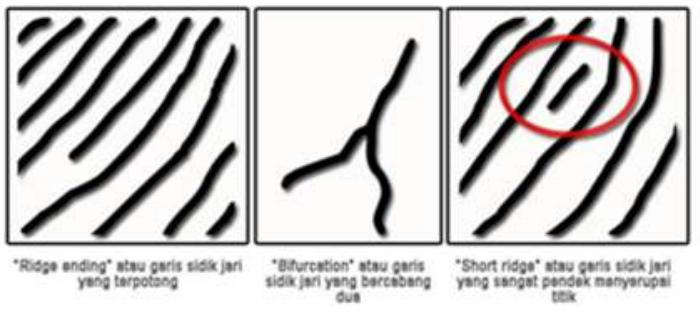

Gambar 2. Sidik Jari

\section{Sensor Finger Scanner}

Sensor finger scanner adalah sebuah perangkat elektronik yang digunakan untuk menangkap gambar digital dari pola sidik jari gambar tersebut disebut pemindai hidup. Pemindaian hidup adalah pemerosesan digital untuk membuat sebuah telplate biometric yang disimpan dan digunakan untuk pencocokan. Ini merupakan ikhtisar dari beberapa sidik jari yang lebih umum digunakan sensor teknologi

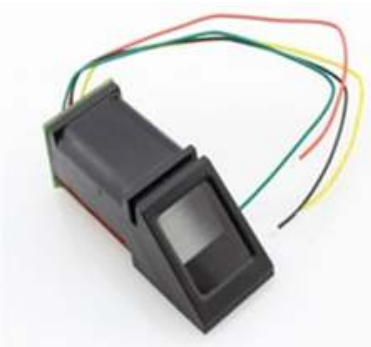

Gambar 3. Sensor Finger Scanner 
Sebuah sistem pemindai sidik jari memiliki dua pekerjaan, yakni mengambil gambar sidik jari, dan memutuskan apakah pola alur sidik jari dari gambar gambar yang diambil sama dengan pola jari ada di database. Ada beberapa cara untuk mengambil gambar sidik jari seseorang, namun salah satu metode yang paling banyak digunakan saat ini adalah optical scanning.

Inti dari pemindai optic charge coupled device (CCD, Peranti tergandeng muatan), sistem sensor cahaya yang sama digunakan pada kamera digital dan camcorder. CCD merupakan sebuah larik sederhana dari diode peka cahaya yang disebut photosite, yang menghasilkan sinyal elektrik yang merespon foton cahaya. Setiap photosite merekam sebuah piksel, titik kecil yang mempresentesikan cahaya dan membentuknya. Piksel-piksel ini membentuk pila terang dan gelap dari sebuah gambar hasil scan sidik jari.

\section{Board Panjerino Uno ATmega328P}

Board Panjerino Uno ATmega328P adalah Board Mikrokontroler (Development Board) menggunakan chip mikrokontroler ATmega328P yang fleksibel dan open-source, Software dan Hardware nya relatif mudah di gunakan sehingga banyak di pakai oleh pemula sampai ahli. Untuk dapat digunakan Board Panjerino Uno ATmega328P di hubungkan ke komputer dengan menggunakan kabel USB atau dengan adaptor atau Power Supply 7-12 V DC. Arduino Uno dapat di gunakan untuk mendeteksi lingkungan dengan membaca data dari berbagai sensor, misalnya jarak, inframerah, suhu, cahaya, ultrasonik, tekanan, kelembaban dan lain lain. [8]

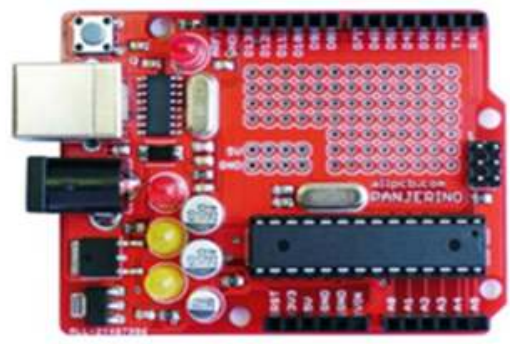

Gambar 4. Pajerino Uno ATmega 328P
Secara garis besar Panjerino Uno ATmega328P mempunyai 14 pin Digital yang dapat di set sebagai Input atau Output dan 6 pin input Analog. Untuk lebih jelasnya untuk spesifikasi Arduino Uno bisa dilihat di bawah ini

Tabel 1. Spesifikasi Panjerino Uno ATmega328P

\begin{tabular}{|c|c|}
\hline Mikrokontroler & ATmega328P \\
\hline Tegangan Operasi & $5 \mathrm{~V}$ \\
\hline Tegangan Masukan & $7-12 \mathrm{~V}$ \\
\hline Tegangan (batas) & $6-20 \mathrm{~V}$ \\
\hline Pin I / O Digital & 54 (yang 14 memberikan keluaran PWM) \\
\hline Pin input analog & $40 \mathrm{~mA}$ \\
\hline Arus DC per I / O Pin & $50 \mathrm{~mA}$ \\
\hline Arus DC untuk Pin 3.3V & $256 \mathrm{~KB}$ \\
\hline Flash Memory & $4 \mathrm{~KB}$ \\
\hline SRAM 8 KB EEPROM & $16 \mathrm{MHz}$ \\
\hline Kecepatan Jam &
\end{tabular}

\section{Mikrokontroler}

Mikrokontroler adalah sebuah sistem komputer fungsional berukuran mikro dalam sebuah chip (integrated circuit) IC yang terdiri dari processor, memori (sejumlah kecil RAM, memori program atau keduanya) dan perlengkapan input output atau antarmuka yang bisa diprogram. Mikrokontroler adalah salah satu dari bagian dasar dari sebuah sistem komputer. Meskipun mempunyai bentuk yang jauh lebih kecil dari suatu komputer pribadi dan komputer mainframe, Mikrokontroler dibangun dari elemen-elemen dasar yang sama. Secara sederhana, komputer akan menghasilkan output spesifik berdasarkan inputan yang diterima dalam program yang dikerjakan

\section{Pemprograman Dasar Panjerino}

Panjerino menggunakan pemrograman dengan bahasa $\mathrm{C}$. Berikut ini adalah sedikit penjelasan yang ditujukan kepada pembaca yang hanya mempunyai sedikit pengalaman pemrograman dan membutuhkan penjelasan singkat mengenai karakter bahasa $\mathrm{C}$ dan software Arduino [9].

\section{Relay}

Relay adalah saklar (switch) yang dioperasikan secara listrik dan merupakan komponen 
Electromechanical (Elektromekanikal) yang terdiri dari 2 bagian utama yakni Elektromagnet (coil) dan mekanikal (seperangkat kontak saklar/switch). Relay menggunakan prinsip elektromagnetik untuk menggerakkan kontak saklar sehingga dengan arus listrik yang kecil (low power) dapat menghantarkan listrik yang bertegangan lebih tinggi. Sebagai contoh, dengan relay yang menggunakan elektromagnet 5 Volt dan $50 \mathrm{~mA}$ mampu menggerakan armature relay yang berfungsi sebagai saklarnya untuk menghantarkan listrik 220 V 2 A. [10]

\section{DFPlayer Mini}

DFPlayer mini merupakan modul pemutar file audio/ module sound player music dengan support format audio seperti file mp3 yang sudah umum dikenal oleh khalayak umum. Bentuk fisik dari DF Player mini ini berbentuk persegi dengan ukuran 20 x $20 \mathrm{~mm}$ yang dimana memiliki 16 kaki pin. Output pada module mp3 mini ini dapat langsung dihubungkan dengan speaker mini ataupun amplifier sebagai pengeras suaranya, [11].

\section{Starting System}

Starting System merupakan proses pemberian putaran awal pada flywheel oleh pinion gear dengan memanfaatkan energi listrik dari baterai yang diubah menjadi energi mekanik oleh motor starter dan starting solenoid yang fungsi utamanya sebagai relay untuk field winding sekaligus sebagai kopling untuk pinion gear-nya.

\section{Metoda Penelitian}

\section{Set Up Parameter Model}

Gambaran umum mengenai skema alat ditunjukan pada gambar 5. Terdiri dari beberapa komponen input yakni finger scanner dan switch power kemudian sinyal akan diolah oleh sebuah processor microcontroller sebagai komponen control yang akan mengirim informasi ke komponen output seperti Relay.

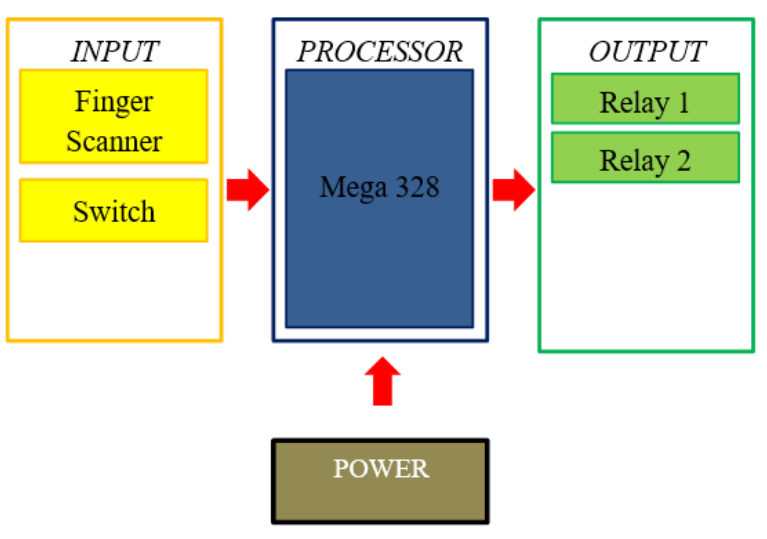

Gambar 5. Perancangan Sistem

Untuk lebih detail dalam prinsip kerja dari peralatan yang di desain, maka dengan ini dibuat flow chart sebagaimana pada Gambar 6 di bawah ini.

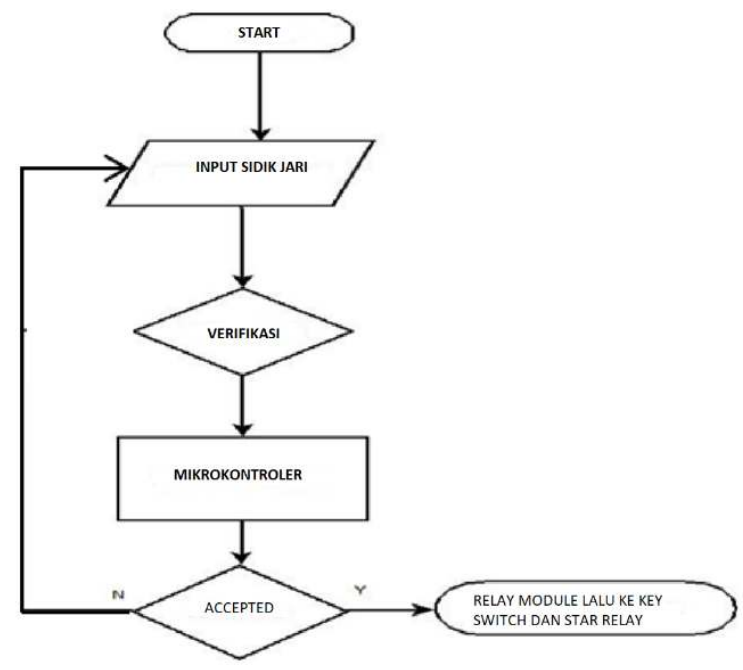

Gambar 6. Flow chart pengujian

Model parameter yang digunakan adalah sidik jari yang akan dibaca oleh optical sensor dari fingerprint module yang kemudian mengubah hasil tangkapan guratan jari kebentuk coding yang dapat dibaca oleh microcontroller, jika sidik jari benar atau telah terdaftar dan memiliki otoritas maka microcontroller akan mengirim sinyal menuju 2 relay module yang kemudian akan memutus nyambungkan arus listrik ke key switch dan start relay, dan jika jari yang dibaca oleh fingerprint module salah atau tidak memiliki 
otoritas maka akan muncul peringatan berupa suara.

Agar alat yang dibuat dapat mengontrol unit alat berat $\mathrm{D} 3 \mathrm{~K}$ untuk menyala dan mengaktifkan starting system maka diperlukan skema pada kelistrikan D3K. Skema rangkaian tersebut haruslah dapat memutus dan menghubungkan kelistrikan pada key start switch dan neutral start relay. Terputus dan terhubungnya kelistrikan pada key start switch dan neutral start relay dikontrol oleh mikroprosesor melalui modul relai dua saluran. Berikut adalah rangkaiannya pada gambar 7 .

\section{Data input Pembacaan Fingerprint}

Perekaman sidik jari bisa dilakukan setelah memasukan coding ke dalam microcontroller. Ada beberapa proses pemrograman dalam pembuatan alat ini yaitu: program/coding pendaftaran dan pembacaan sidik jari, coding sound peringatan, coding fingerprint module.

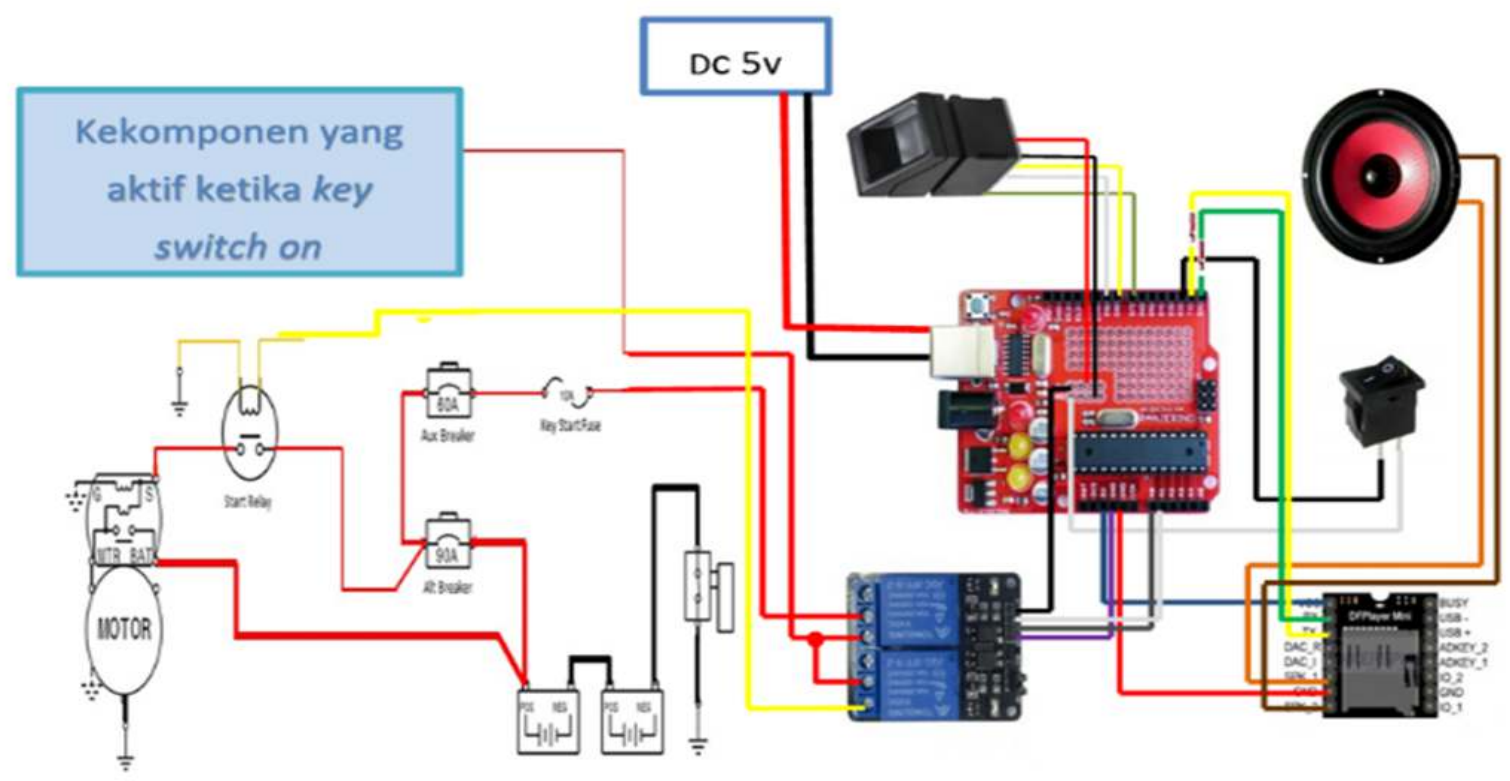

Gambar 7. Skema rangkaian BSS dan sistim starting unit D3K

\section{Hasil Penelitian}

\section{Hasil Pengujian Komponen Kontrol}

Dengan dilakukan pengujian pada alat biometric ini memberikan beberapan hasil sebagai berikut : bahwa pada pengujian jari yang valid yaitu jari yang sudah didaftarkan terlebih dahulu di software SFGDemo. Hasilnya dari 10 kali pengujian dan dengan jari jempol tangan kanan $100 \%$ berhasil;

Dan pada pengujian jari yang invalid adalah jari yang belum didaftarkan terlebih dahulu di software SFGDemo. Hasilnya dari 10 kali pengujian dan dengan jari jempol tangan kanan $100 \%$ tidak teridentifikasi, untuk hailnya dapat dilihat pada Tabel 2 di bawah ini.

Tabel 2. Pengujian Scanning Microcontroller

\begin{tabular}{|c|c|c|c|c|}
\hline No & Pemilik Sidik Jari & Status Sidik Jari & $\begin{array}{c}\text { Respon } \\
\text { Fingerprint }\end{array}$ & $\begin{array}{c}\text { Indikator } \\
\text { Lamp Relay }\end{array}$ \\
\hline 1 & Jempol Operator A & Tidak Terdaftar & Not Valid & Hidup \\
\hline 2 & Jempol Operator B & Tidak Terdaftar & Not Valid & Hidup \\
\hline 3 & Jempol Operator C & Terdaftar & Valid & Mati \\
\hline
\end{tabular}

Pengujian jari yang valid akan diuji 3 macam kondisi yaitu kondidi jari kering, berkeringat dan berdebu, pengujian dilakukan sebanyak 10 kali, hasil yang diperoleh bahwa 
rata-rata dengan jari kering tingkat keberhasilannya $100 \%$ pada saat mesin dihidupkan dan dimatikan dengan jari jempol tersebut. Begitupula dengan pengujian dengan jari berkeringat dan berdebu di mana tingkat keberhasilan mesin pada waktu dihudupkan dan dimatikan adalah masing-masing diperoleh rata-rata untuk berkeringat $80 \%$ dan berdebu $10 \%$, untuk hasilnya dapat dilihat pada Tabel 3 di bawah ini.

Tabel 3. Pengujian Validasi Sidik Jari

\begin{tabular}{|c|c|c|c|c|}
\hline \multirow{2}{*}{ No } & \multirow{2}{*}{ Pemilik Sidik Jari } & \multirow{2}{*}{ Status Sidik Jari } & \multicolumn{2}{|c|}{ Kondisi Mesin } \\
\cline { 4 - 5 } & & & Hidup & Mati \\
\hline 1 & Jempol Operator A & Kering & $100 \%$ & $100 \%$ \\
\hline 2 & Jempol Operator B & Berkeringat & $80 \%$ & $80 \%$ \\
\hline 3 & Jempol Operator C & Berdebu & $10 \%$ & $10 \%$ \\
\hline
\end{tabular}

\section{Pengujian Starting System}

Pada umumnya starting system memiliki 4 elemen utama yaitu key star switch, start relay, starting motor solenoid, dan starting motor. Disini key satr switch diganti dengan 2 relay module, yang mana memiliki kapasitas 515 A. Pada saat pengujian berlangsung didapat bahwa ambient temperature-nya adalah 27 derajat Celcius dan sistem kelistrikan memiliki tegangan 24 volt dan voltase yang didapat selama crank adalah 23 volt. Hasil ini masih sesuai dengan toleransinya dari pengaruh ambient temperature terhadap tegangan baterai selama cranking.

Selain pengaruh ambient temperature terhadap tegangan baterai selama crank, voltage drop juga diuji, adapun hasilnya disajikan dalam Tabel sebagai berikut :

Tabel 2. Hasil pengujian voltage drop

\begin{tabular}{c|c|c|}
\hline No & Circuit Tested & 24 Volt System \\
\hline 1 & Battery post "." to starting motor terminal"." & $0,6 \mathrm{~V}$ \\
\hline 2 & Drop across the disconnect switch & $0,5 \mathrm{~V}$ \\
\hline 3 & Battery post "+" to terminal of the starting motor sol"+" & $0,6 \mathrm{~V}$ \\
\hline 4 & Solenoid terminal "Bat" to the selenoid terminal "mtr" & $0,7 \mathrm{~V}$ \\
\hline
\end{tabular}

Berdasarkan Tabel 2 kondisi kelistrikan dari unit ini masih dalam kondisi cukup baik karena semua item masih masuk didalam batas toleransi.

\section{Standar Operational Prosedur (SOP) Prosedure Pendaftaran Sidik Jari}

Jari harus dalam kondisi bersih dan kering sebelum melakukan pendaftaran sidik jari agar pembacaan sidik jari akurat dan tidak mengotori optical sensor dari modul fingerprint module itu sendiri, Berikut ini adalah prosedur pendaftaran sidik jari:

1. Koneksikan kabel catu daya untuk catu daya microcontrollernya;

2. Tekan switch pendaftaran ke posisi on;

3. Tekan tombol reset;

4. Tunggu lampu fingerprint module meyala kemudian tempelkan jari yang akan didaftar hingga lampu mati;

5. ketika lampu fingerprint module menyala tempelkan jari sekali lagi untuk memverifikasi;

6. Matikan switch untuk pendaftaran dan tekan tombol reset maka jari telah terdaftar.

\section{Standar operational prosedur untuk menghidupkan mesin}

Pastikan jari dalam kondisi bersih dan kering sebelum mengoperasika alat ini. Berikut ini adalah prosedurnya:

1. Sambungkan catu daya untuk microcontrollernya;

2. Aktifkan disconnect switch;

3. Pasang jari pertama untuk menyalakan kunci kontak;

4. Pasang jari kedua untuk cranking engine;

5. Pasang jari yag ketiga kalinya untuk mematikan engine.

Itu adalah Standar Operasional Prosedur (SOP) dari alat ini, selalu ikuti SOP agar umur dari alat tetap terjaga dan demi keselamatan kita semua.

\section{Kesimpulan}

1. Dari hasil pembuatan starting system dengan pengenalan sidik jari, dapat disimpulkan bahwa sistem dapat berkomunikasi dengan modul fingerprint berupa "On kontak", 
"Starter motor", "Off kontak" dan "eror". Dari tiga jenis sidik jari (jempol kiri, telunjuk kiri, dan tengah kiri) pada lima orang yang menjadi sampel, tingkat kepekaan sensor berariasi. Hal ini dikarenakan pada kualiatas sidik jari saat menempel pada sensor;

2. Sistem akan menghidupkan peringatan saat ada sidik jari yang tidak sesuai menempel disensor dan setelah 5 kali akan terblokir dengan sendirinya. Sensor hanya akan berkominukasi dengan sidik jari yang tersimpan di dalam sensor;

3. Biometric starting system ini dapat diaplikasikan pada semua jenis alat berat yang menggunakan sistem key switch 10 Ampere. Dengan adanya teknologi ini diharapkan dapat meminimalisir traffic accident akibat operator yg tidak memiliki ijin atau belum mendapat pelatihan kompetnsi terlebih dahulu.

\section{Saran}

1. Diharapkan teknologi biometric starting system ini dapat diaplikasikan di seluruh industri pertambangan yang menggunakan kendaraan yg memiliki resiko mengalami traffic accident. Terutama Light Vehicle (LV) yang melaju di jalur houling yang memiliki resiko kecelakaan sangat tinggi jika pengemudinya tidak berpengalaman dan tidak melalui proses pelatihan kompetensi untuk mendapatkan simper;

2. Diharapkan juga alat ini untuk dapat dikembangkan, karena masih banyak fiturfitur yang dapat ditambahkan seperti penghitung waktu kerja unit, digabungkan dengan sistem absensi operator, acuan untuk penghitungan waktu kerja unit jika unit ini akan disewakan.

\section{Daftar Pustaka}

[1] U. Usman, A. Abdul Azis Rahmansyah, and N. Fajri Apriadi, "Rancang Bangun Pagar Otomatis dengan Finger Print Berbasis Mikrokontroller," JTT (Jurnal Teknol. Ter., 2017, doi: 10.31884/jtt.v3i1.3.

[2] D. Saputra and A. H. Masud, "Akses Kontrol Ruangan Menggunakan Sensor Sidik Jari Berbasis Mikrokontroler Atmega328p," Sentika, 2014.

[3] S. Lumban Tobing, "Rancang Bangun Pengaman Pintu Menggunakan Sidik Jari (Fingerprint) Dan Smartphone Android Berbasis Mikrokontroler Atmega8," Tek. Elektro Univ Tanjungpura Pontianak, 2015, doi: 10.1017/CBO9781107415324.004.

[4] E. Yuliza and T. U. Kalsum, "Alat Keamanan Pintu Brankas Berbasis Sensor Sidik Jari Dan Passoword Digital Dengan Menggunakan Mikrokontroler Atmega 16," J. Media Infotama, 2018.

[5] KENR5969-04, Schematic Electric Dozer D3K (Media Number KENR5711-04). 2017.

[6] Training Center [TC]. Fundamental of Electric, PT. Trakindo Utama, Cileungsi, Bogor. 2008.

[7] N. Suryani, "Pengenaalan Sidik Jari dengan Metoda Pencocokan Minusi," Universitas Komputer Indonesia, Jakarta, 2006.

[8] I. P, "Pengertian Arduino Uno Mikrokontroler Atmega328," 06 Juli, 2015.

[9] N. G. A. P. H. Saptarini, R. A. Hidayat, and P. I. Ciptayani, "Ajarincode: aplikasi pembelajaran bahasa pemrograman berbasis web," Just Ti, 2018.

[10] M. H. Muhamad Saleh, "Rancang Bangun Sistem Keamanan Rumah Menggunakan Relay," "Jurnal Teknol. Elektro, Univ. Mercu Buana, vol. 8, no. 3, pp. 181-186, 2017.

[11] E. W. Vetricha Wulandari, "Automated Trash Sorting Design Based Microcontroller Arduino Mega 2560 with LCD Display and Sound Notification," in IOP Conference Series: Materials Science and Engineering, 2020, doi:10.1088/1757-899X/725/1/012054. 